УДК 159.973

DOI https://doi.org/10.26661/2310-4368/2021-2-2

\title{
ВПЛИВ ІНКЛЮЗИВНОГО СЕРЕДОВИЩА НА ФОРМУВАННЯ САМОСВІДОМОСТІ У ДІТЕЙ 3 ПОРУШЕННЯМИ ІНТЕЛЕКТУ
}

\author{
Бровченко А. К. \\ кандидат психологічних наук, дочент, \\ дочент кафедри корекиійної освіти та спеціальної психологї \\ К3 «Харківська гуманітарно-педагогічна академія» Харківської обласної ради \\ пров. Руставелі, 7, Харків, Украӥна \\ orcid.org/0000-0003-2208-296X \\ rideamusab@gmail.com
}

Бужинська С. М.

кандидат психологічних наук, дочент,

дочент кафедри педагогіки, психології, початкової освіти та освітнього менеджменту

К3 «Харківська гуманітарно-педагогічна академія» Харківської обласної ради

пров. Руставелі, 7, Харків, Україна

orcid.org/0000-0002-5103-0053

svetlanakh314@gmail.com

\section{Даніліч-Скакун А. А.}

викладач кафедри педагогіки, психології, початкової освіти та освітнього менеджменту

К3 «Харківська гуманітарно-педагогічна академія» Харківської обласної ради

пров. Руставелі, 7, Харків, Украӥна

orcid.org/0000-0003-1167-605X

danilichalla30@gmail.com

\begin{abstract}
Ключові слова: інклюзивне середовище, формування самосвідомості, самосвідомість дітей $з$ порушеннями інтелекту, ставлення педагогів та однокласників до дітей $з$ порушеннями інтелекту як фактор формування самосвідомості, психологічні умови створення оптимального інклюзивного середовища.
\end{abstract}

У статті аналізується проблема формування самосвідомості дітей 3 порушеннями інтелекту в умовах інклюзивної освіти. Створення оптимального інклюзивного середовища в статті трактується як головна умова досягнення оптимального рівня розвитку самосвідомості у дітей, чиї особливості заважають нормальному процесу взаємодії зі світом та ускладнюють процеси самопізнання, адекватного оцінювання власних якостей та здібностей. Авторами описані прояви самосвідомості дітей 3 порушеннями інтелекту, спільні 3 тими, що притаманні дітям, які розвиваються нормально, а також специфічні, обумовлені як первинними порушеннями, так і впливом середовища. Проведений аналіз деяких факторів, що впливають на виникнення негативних явищ в процесі формування образу «Я», самооцінки і рівня домагань у означеної категорії дітей, а зрештою приводять до складностей їх соціалізації. Відзначено, що отримані різними дослідниками дані про неадекватно завищену або занижену самооцінку у дітей з легкими порушеннями інтелекту пов'язані не стільки $з$ особливостями їх дефекту, скільки 3 впливом ставлення оточуючих людей (батьків, педагогів та однолітків), налаштованих позитивно та дружньо, або вороже, зневажливо чи байдуже.

Авторами описані основні ознаки позитивного інклюзивного середовища, яке сприяє результативному формуванню самосвідомості дітей $з$ порушеннями інтелекту, а також перелічені основні психологічні умови, без яких створення такого середовища $є$ неможливим. Серед 
цих умов найбільш значущими є: попередня психологічна підготовка педагогів, що будуть працювати у інклюзивних класах, підготовка дітей, що розвиваються нормально, до толерантного сприйняття включеної дитини $з$ особливостями розвитку та співпраці 3 нею, просвітницька робота з батьками, від яких в основному залежать загальні настанови здорових дітей щодо тих, хто за певними ознаками відрізняється від більшості. В статті наголошується, що проаналізовані умови формування самосвідомості дітей з порушенням інтелекту в процесі інклюзивного навчання можуть привести до конструктивного вирішення означеної проблеми тільки в сукупності.

\title{
INFLUENCE OF INCLUSIVE ENVIRONMENT ON THE FORMATION OF SELF-CONSCIOUSNESS IN CHILDREN WITH INTELLECTUAL DISORDERS
}

\author{
Brovchenko A. K. \\ Candidate of Psychological Sciences, Associate Professor, \\ Associate Professor at the Department of Correctional Education and Special Psychology \\ Municipal Establishment "Kharkiv Humanitarian Pedagogical Academy" \\ of Kharkiv Regional Council \\ Rustaveli Lane, 7, Kharkiv, Ukraine \\ orcid.org/0000-0003-2208-296X \\ rideamusab@gmail.com
}

Buzhynska S. M.

Candidate of Psychological Sciences, Associate Professor,

Associate Professor at the Department of Pedagogy, Psychology, Primary Education

and Educational Management

Municipal Establishment "Kharkiv Humanitarian Pedagogical Academy"

of Kharkiv Regional Council

Rustaveli Lane, 7, Kharkiv, Ukraine

orcid.org/0000-0002-5103-0053

svetlanakh314@gmail.com

Danilich-Skakun A. A.

Lecturer at the Department of Pedagogy, Psychology, Primary Education

and Educational Management

Municipal Establishment "Kharkiv Humanitarian Pedagogical Academy"

of Kharkiv Regional Council

Rustaveli Lane, 7, Kharkiv, Ukraine

orcid.org/0000-0003-1167-605X

danilichalla30@gmail.com

Key words: inclusive environment, the formation of self-awareness, self-awareness of children with intellectual disabilities, the attitude of teachers and classmates to children with intellectual
The article analyzes the problem of the formation of self-awareness in children with intellectual disabilities in the context of inclusive education. The creation of an optimal inclusive environment is interpreted as the main condition for achieving an optimal level of self-awareness in children, whose features interfere with the normal process of interaction with the world and complicate the processes of self-knowledge, adequate assessment of their own qualities and abilities. The authors describe manifestations of self-awareness 
disabilities as a factor in the formation of self-awareness, psychological conditions for creating an optimal inclusive environment. of children with intellectual disabilities, common with those characteristic of children, which develop normally, as well as specific ones, caused by primary disorders and the influence of the environment. The analysis of some factors influencing the emergence of negative phenomena in the process of forming the image of "I", self-esteem and the level of claims in this category of children, and ultimately lead to the difficulties of their socialization. It is noted that the data obtained by various researchers on inadequately high or low self-esteem in children with mild intellectual disabilities are associated not so much with the peculiarities of their defect as with the influence of the attitude of the surrounding people (parents, teachers and peers), who are positive and friendly, or hostile, dismissive and indifferently.

The authors describe the main signs of a positive inclusive environment that contributes to the effective formation of self-awareness of children with intellectual disabilities, and also lists the main psychological conditions without which the creation of such an environment is impossible.

Among these conditions, the most significant are: preliminary psychological training of teachers working in inclusive classes, preparation of children who develop normally for a tolerant perception of a child with disabilities and cooperation with him, educational work with parents, on whom mainly depend general attitudes of healthy children towards those who differ from the majority on certain grounds. The article notes that the analyzed conditions for the formation of self-awareness of children with intellectual disabilities in the process of inclusive education can lead to a constructive solution to this problem only in aggregate.
Постановка проблеми. Однією 3 головних умов формування людини як особистості, що здатна до самозмінення, перетворення власного життя та повноцінного включення у соціум $\epsilon$ пізнання нею самої себе, визначення певного ціннісного ставлення до себе, уявлення про власні можливості, тобто побудування чітко вираженої самосвідомості.

Багатьма авторами у межах спеціальної психології відзначається, що проблема формування самосвідомості дітей з порушеннями розвитку представляється ще більш актуальною, ніж при розвитку нормативному, тому що процес цей виявляється тісно пов'язаним 3 головною метою корекційно-розвивальної роботи з цими дітьми, а саме $з$ їх адаптацією до життя у суспільстві в ролі повносправних його членів. Одним із головних завдань на шляху до основної мети в роботі педагогів і психологів 3 дітьми, що мають порушення інтелекту, є розвиток у них позитивного ставлення до оточуючих і до себе та оптимістичного уявлення про подальше розгортання власної особистості у взаємодії зі світом. Особливо важливим це $є$ для дітей 3 легким ступенем інтелектуальних порушень, які навчаються у масових школах і мають можливість повною мірою адаптуватися в соціумі за умови адекватного психолого-педагогічного супроводу.

У ранніх роботах дослідників, присвячених психології дітей і підлітків 3 інтелектуальними порушеннями, увага в основному приділялася розкриттю особливостей вищих психічних функцій, що стосується вирішення найбільш актуальних на той час задач їх навчання і професійного спрямування, а питання розвитку особистості розглядалися тільки побіжно. Більшість авторів, що описують деякі прояви Я-концепції дітей 3 порушеннями інтелекту, вважають, що формування іiі проходить ті ж етапи, що й у дітей 3 нормальним розвитком, але відмічають в цьому процесі певні якісні та кількісні відмінності, притаманні досліджуваній категорії [3, 4]. Досліджень розвитку самосвідомості, самосприйняття, уявлень про себе дітей з вадами розвитку до останніх десятиліть проводилося вкрай мало, особливо це стосується вітчизняної спеціальної психології, що дозволяє вважати проблему визначення структури, змісту та становлення і цілеспрямованого формування дитячої Я-концепції при порушеному розвитку недостатньо освітленою.

Процес усвідомлення себе як фізичної, духовної та соціальної істоти у дітей 3 інтелектуальними порушеннями має свої особливості, знання яких педагогами, психологами та батьками зумовить повне та глибоке розуміння внутрішнього світу цих дітей, допоможе побудувати правильну взаємодію з ними і ефективно впливати на їх розвиток та адаптацію. Знання специфіки формування Я-концепції дітей з порушеннями інтелекту надає можливість побудувати ефективну психокорекційну роботу, спрямовану на розвиток навичок соціальної поведінки, впевненості у влас- 
них силах, самостійності у вирішенні життєвих завдань. Це набуває особливої актуальності під час впровадження інклюзивної освіти, покликаної створювати корекційне та підтримуюче середовище для дітей з вадами розвитку. Під поняттям інклюзивного середовища, за словами І. Б. Кузавої, розуміється життєвий простір, що забезпечує підвищення почуття власної гідності та впевненості у собі дітей, які потребують корекції психофізичного розвитку [2].

Мета статті. Метою даної статті став аналіз специфіки самосвідомості у дітей з порушеннями інтелекту, визначення ролі інклюзивного середовища у формування Я-концепції дітей з вадами інтелектуального розвитку, зокрема негативних наслідків недостатньо або неправильно організованого освітнього середовища, а також окреслення основних напрямків і умов оптимізації означених процесів в інклюзивній освіті.

Виклад основного матеріалу дослідження. У сучасній спеціальній психології спостерігається поступове звернення до проблеми самосвідомості, як однієї з найбільш актуальних, в межах якої почали вивчатися питання самоставлення, самосприйняття дітей з вадами розвитку, формування ïх самооцінки, оцінки власних здібностей та перспектив розвитку. Відомо, що основу інтелектуального компонента самооцінки становить порівняння себе 3 іншими людьми, зіставлення своїх якостей 3 внутрішніми еталонами або результатами діяльності інших, оцінка ступеня неузгодженості цих двох величин. За загальними закономірностями побудови Я-концепції, результат оцінки самої себе дитиною з інтелектуальними порушеннями зв'язується зі ставленням оточуючих людей і впливає на подальші взаємовідносини зі світом. Тобто, сприйняття і оцінка власних властивостей спирається на уявлення про якості, які $є$ інтеріоризованими настановами суспільства про належне. Тому, звичайно, самосприйняття, самооцінка та самоставлення будуть залежати одночасно як від середовищних впливів, так і від рівня сформованості у людини пізнавальних здібностей.

3 ранніх етапів життя у дітей з вадами розвитку виникають труднощі самопізнання, викликані внутрішніми і зовнішніми чинниками, що проявляється навіть на рівні розрізнення власного Я та оточуючого світу в перші місяці життя. Процес формування самосвідомості дітей з вадами інтелектуального розвитку супроводжується неповним, неточним сприйняттям самих себе, складністю порівняння себе з оточуючими та звернення до них як до взірця у власній поведінці. Властива дітям 3 порушенням інтелекту слабкість регулюючої функції мислення обумовлює їх некритичність по відношенню до своїх вчинків [4]. А це орієнтує їх звертатися до зовнішніх оцінок, які також сприймаються некритично, безумовно і неповно. У дослідженнях Є. С. Слепович [6] показано, що діти із затримкою психічного розвитку (ЗПР) оцінюють себе, спираючись на власні вчинки у конкретній ситуації і орієнтуючись на висловлювання дорослих (батьків та педагогів). Уявлення ж про власні особистісні якості довго залишаються у цих дітей неповними.

Для цієї категорії дітей, особливо в підлітковому віці, підвищується роль спілкування у побудові уявлень про себе, набуває значення ставлення батьків, сім’і, пізніше педагогів i, нарешті, референтної групи. Це ставлення є для них показником рівня власної цінності та основою самосвідомості. Одночасно дітям 3 порушеннями інтелекту складно подивитися на себе очима інших, якщо зовнішні оцінки проявлені недостатньо чітко та однозначно.

Експериментальне вивчення самооцінки у дітей 3 порушеннями інтелекту демонструє іiі неадекватність в бік завищення. Ще в 1939 році А. В. Занков, описуючи самооцінку розумово відсталих дітей, відзначав, що вона завищена, і пояснює це процесами іï псевдокомпенсації. У більш пізніх дослідженнях описані схожі закономірності. Хоча з віком (у підлітків та юнаків з вадами інтелектуального розвитку) адекватність самооцінки зростає [3].

Але достатньо частою $є$ описана у деяких авторів протилежна тенденція, що проявляється в зниженні самоповаги, в почутті власної неповноцінності, меншовартості у підлітків, які мають порушення Я-концепції через нерозвинутість процесів самосприйняття. За результатами дослідження А. А. Смирнової, у дітей з ЗПР обмеженість мовного спілкування сприяє розвитку сором'язливості, невпевненості, замкнутості, негативізму, почуття неповноцінності [7]. Такі ознаки самоставлення у дітей 3 незначними інтелектуальними порушеннями, за дослідженням T. I. Кузьміної, можуть сприяти формуванню асоціальної Я-концепції в рамках протестної реакції у зв'язку з усвідомленням свого дефекту [3].

При сприятливому соціальному оточенні та нормальному психічному розвитку соціалізація дитини, засвоєння і присвоєння нею суспільних норм, цінностей, уявлень про належне відбувається природно в процесі спілкування 3 дорослими і однолітками. До того ж відомо, що переживання власної успішності створює основу для розвитку адекватної позитивної самооцінки будьякої людини, а якщо дитина зростає та виховується в умовах занадто складних вимог середовища, перспектив, що не відповідають потребам і можливостям дитини, створюються суттеві труднощі на шляху до самореалізації, яка стає майже неможливою [8]. Діти с порушенням інтелекту 
часто перебувають в умовах соціальної депривації у зв'язку з особливостями їх розвитку, що ускладнює взаємодію з суспільством.

В сучасній спеціальній педагогіці все частіше наголошується необхідність створення такого життєвого простору, що забезпечує підвищення почуття власної цінності та впевненості в собі у дітей з порушеннями розвитку, такого соціокультурного середовища, яке враховувало б своєрідність шляхів формування їх самосвідомості $[2 ; 5 ; 8]$. I, як показує практика, створення такого середовища на базі закладів спеціальної освіти виявляється недостатнім, що актуалізує звернення до аналізу процесів формування самосвідомості дітей 3 порушеннями розвитку в умовах інклюзивної освіті.

Одним із факторів, який обов'язково треба враховувати в процесі створення необхідного середовища, $є$ ставлення та особисті установки більшості учасників освітнього процесу (учнів, які розвиваються нормально, їх батьків та педколективу) до дітей $з$ особливими освітніми потребами. Проведені дослідження дають можливість спостерігати коливання у цьому ставленні від позитивного та толерантного прийняття, до гостро негативного відторгнення. Дослідниками описується певна «ієрархія популярності» різних видів недостатності, серед яких займають найнижче місце діти 3 вадами психічного здоров'я або інтелектуального розвитку, як ті, що найменш відповідають нормативним вимогам суспільства. На думку А. Н. Щербакової, означена закономірність пов'язана $з$ тим, що при наявності проблем ментального розвитку стандартні позиції соціальної успішності є важкодосяжними, а інших критеріїв самореалізації суспільство зараз не бачить [8].

Досвід спостереження за дитячими спільностями (особливо підлітковими) приводить до висновків про те, що часто здорові діти з вираженою жорстокістю оцінюють дефекти тих, хто суттєво відрізняється від більшості, в результаті чого діти, які мають відхилення у розвитку, замикаються в собі, відчувають власну неповноцінність та незначимість для оточуючих, порівнюючи себе 3 однолітками, вони схильні відчувати почуття провини, їм притаманні надмірне самокопання, незадоволеність собою [1].

В дослідженні А. А. Смирнової описані спостереження вчителів, згідно з якими однокласники негативно ставляться до підлітків з ЗПР в умовах інклюзивної освіти, ігнорують їх. При цьому самі діти з ЗПР намагаються уникнути будь-якої участі в шкільному житті, болісно переносять критичні зауваження на свою адресу та страждають від надлишкової сором'язливості [7]. Порівняно 3 цим, підлітки, які навчаються в однорідному середовищі, з тими, хто має схожі психофізіоло- гічні особливості, як відмічає Е. Б. Дунаєвська [1], більш схильні приймати себе, переживати власне «Я» як внутрішній стрижень, вважати основним джерелом активності власну особистість. Хоча, як зазначалося вище, самооцінка їх буває неадекватно завищеною.

Чи значить це, що інклюзивна освіта, однією 3 головних задач якої є інтеграція дітей з порушеннями у суспільство та успішна їх соціалізація, не здатна впоратися з покладеними на неї функціями? Звичайно, ні, складність вирішення проблеми не означає іiї безперспективності. Поглиблене вивчення самосвідомості дітей та підлітків, що навчаються в системі інклюзивної освіти, без замовчування реальної ситуації, допоможе створити необхідні умови для розвитку особистості, готової до саморозвитку, розуміння себе і усвідомлення власних потреб. Необхідною передумовою позитивного розвитку власного «Я» є відчуття дитиною захищеності та довіри, які повинні супроводжувати іiї у всіх спільнотах, в яких вона перебуває протягом життя. Проекти середовищ, які забезпечують ефективний розвиток осіб 3 порушеннями інтелекту, повинні уявляти собою моделі соціуму, в якому вбачається майбутнє життя цієї категорії осіб. Вони повинні забезпечити стимуляцію позитивного особистісного потенціалу дітей 3 порушеннями розвитку.

Виділяючи три основних компоненти структури самосвідомості - когнітивний, афективний i регулятивний, можна визначити три основні напрями діяльності психолого-педагогічного супроводу в інклюзивних закладах освіти. Реалізація когнітивного компоненту полягає у створенні позитивного образу «Я» дітей 3 порушеннями інтелекту, афективний компонент пов'язується 3 забезпеченням безоціночного ставлення педагогів та однолітків, а регулятивний визначається формуванням у дітей здібності до саморегуляції поведінки та емоційних станів. Всі три напрямки формування самосвідомості виявляються тісно пов'язаними між собою, тому що створення у цієї категорії дітей адекватних внутрішніх уявлень про себе відбувається під впливом оцінок та проявів ставлення з боку оточуючих людей - педагогів, і пізніше однолітків. А образ «Я» і чітка оцінка власних можливостей сприяє активному прояву себе у світі (регулятивний та діяльнісний компонент самосвідомості) [5].

Дослідники, що намагаються практично підійти до вирішення проблем формування самосвідомості дітей та підлітків з порушеннями інтелекту, називають гуманістично-особистісний підхід до дитини невід'ємною частиною інклюзивної освіти, що відповідає за формування позитивної Я-концепції. А конкретними кроками до вирішення поставлених задач називають прагнення 
педагогів бачити в кожній дитині унікальну особистість; створення ситуацій успіху, підтримки, доброзичливості, в чому має потребу кожна дитина, а тим більше дитина з інтелектуальними порушеннями, які цьому успіху заважають; допомога у самореалізації дітей та підлітків в позитивній діяльності [5; 6; 7].

Спираючись на проаналізовані специфічні прояви самосвідомості дітей та підлітків 3 порушеннями інтелекту, можна визначити першочергові психолого-педагогічними умови іï формування шляхом створення відповідного підтримуючого середовища в умовах інклюзивної освіти. Цими умовами є:

- Психологічна підготовка педагогів, що будуть працювати у інклюзивних класах 3 дітьми, які мають інтелектуальні порушення. Вище згадувалася проблема ігнорування включених дітей однокласниками під час освітнього процесу та в неформальному спілкуванні. Але часто ігнорування починається саме 3 педагогів, що у роботі своїй перш за все орієнтуються на учнів, які не потребують особливої уваги і використання особливих методів для засвоєння програмного матеріалу. Якщо педагоги-дефектологи готуються до зустрічі з цією категорією дітей декілька років, то для вчителів-предметників ця зустріч часто стає неочікуваною i небажаною. Досліджень ставлення педагогів до дітей 3 відхиленнями у розвитку, звичайно, не проводилося, що пов'язано 3 певними етичними складностями, але спостереження і досвід взаємодії вчителів та «складних» дітей у освітньому середовищі дає можливість припустити, що негативні емоції (тривога, роздратування, а іноді навіть відраза) періодично у них помічаються.

Треба відмітити, що саме психологічній підготовці (паралельно 3 методичною) педагогів, налаштуванню їх на позитивне ставлення до дітей 3 особливостями розвитку необхідно приділяти увагу, починаючи з періоду надбання ними вищої педагогічної освіти, і підкріплювати це позитивне налаштування у процесі педагогічної практики.

- Пропедевтична психологічна підготовка дітей, що розвиваються нормально, до толерантного сприйняття включеної дитини 3 особливостями розвитку. Сумісна робота педагогів та психологів по навчанню дітей основам комунікації, навичкам допомагаючої поведінки, прийняттю різноманітності людської природи і орієнтація їх на вищі суспільні цінності також повинна відбуватися не тоді, коли дитина 3 інтелектуальними порушеннями вже потрапила у інклюзивне середовище, а за декілька років до цієї події.

- Підготовча просвітницька робота з батьками, від яких в основному залежать загальні настанови здорових дітей щодо тих, хто за певними озна- ками відрізняється від більшості. Часто навіть у спеціальних школах джерелом невдоволення поведінкою особливої дитини, що обумовлена іiі порушеннями, є найбільш активні батьки. Звичайно, в повній мірі подолати можливі негативні наслідки подібних непорозумінь вряд чи вийде шляхом ознайомлення батьків 3 межами корекційних впливів у спеціальній педагогіці та психології, але до сімей повинна бути донесена позиція освітнього закладу щодо принципів толерантності у інклюзивній освіті.

- Створення учасниками освітнього процесу психологічно комфортної атмосфери інклюзивного навчання, побудова освітнього простору, що сприяє прояву кожної особистості, не залишаючи поза межами педагогічної уваги жодної дитини, яка може вважатися комусь «безперспективною» і не вартою витрачених на неї ресурсів.

- Впровадження інтерактивних педагогічних технологій в процес інклюзивного навчання, які активізують розумову діяльність дітей з інтелектуальними порушеннями та одночасно включають їх у взаємодію з однокласниками, що 3 двох сторін впливає на формування самосвідомості.

- Розширення системи психологічних заходів (тренінгів будь якого напрямку, в яких приймають участь всі без виключення діти, індивідуальної роботи 3 корекції самооцінки та самоставлення), яким часто приділяється менше значення, ніж проблемам навчання та інтелектуального розвитку.

Перелічені умови формування самосвідомості підлітків 3 порушенням інтелектуального розвитку в процесі інклюзивного навчання можуть привести до конструктивного вирішення означеної проблеми тільки в сукупності та при залученні всіх фахівців, що працюють 3 цими дітьми.

Висновки. Цілеспрямоване формування самосвідомості дітей 3 порушеннями інтелекту стає одним із головних кроків на шляху до їх соціалізації, однак результати аналізу даної проблеми показують, що при наявності означених порушень процес цей відбувається складно і без спеціально організованого психолого-педагогічного супроводу та створення доброзичливого середовища може привести до небажаного результату - неадекватної самооцінки, викривлення уявлень про себе, низького рівня домагань. В рамках інклюзивної освіти ця категорія дітей потребує постійної підтримки і створення психолого-педагогічних умов для формування самосвідомості. Серед цих умов, на базі яких і створюється середовище, що сприяє розвитку Я-концепції дітей, найбільш важливими $\epsilon$ психологічна готовність педагогів до взаємодії 3 дітьми, що мають порушення інтелекту, готовність дітей, які розвиваються нормально, до толерантного, доброзичливого сприйняття включених 
однокласників, а також до спілкування і співпраці 3 ними. Важливим також $є$ формування адекватного ставлення батьків, що виховують здорових дітей, до цієї категорії учнів.

Значення набувають також інші психолого-педагогічні умови, що визначаються як загальними характеристиками процесу формування самосвідомості, так і специфічними, притаманними йому саме в інклюзивній освіті дітей, що мають вади інтелектуального розвитку. Але найменш вивченим $є$ визначення ролі у створенні оптимального інклюзивного середовища i впливу на формування самосвідомості рівня психологічної готовності та емоційно-ціннісного ставлення до дітей педагогів інклюзивних шкіл, що можна вважати перспективним напрямком дослідження.

\section{ЛІТЕРАТУРА}

1. Дунаевская Э. Б. Особенности самоотношения подростков, обучающихся в системе инклюзивного образования. Проблемы современного педагогического образования. 2018. № 60-3. Режим доступа: URL: https://cyberleninka.ru/article/n/osobennosti-samootnosheniya-podrostkov-obuchayuschihsya-vsisteme-inklyuzivnogo-obrazovaniya (дата обращения: 18.06.2021).

2. Кузава І. Б. Роль інклюзивного середовища у формуванні особистості дошкільників, які потребують корекції психофізичного розвитку. Педагогічна освіта: теорія і практика. 2012. Вип. 11. C. 315-318.

3. Кузьмина Т. И. Динамика формирования Я-концепции у лиц с легкой степенью умственной отсталости : диссертация ... кандидата психологических наук : 19.00.10. Москва, 2009. 270 с.

4. Морозова Н. Л. Особенности формирования самовосприятия младших школьников с интеллектуальным недоразвитием : диссертация ... кандидата психологических наук : 19.00.10; [Место защиты: Нижегор. гос. пед. ун-т]. Нижний Новгород, 2008. 214 с.

5. Педагогика и психология инклюзивного образования : учебное пособие. Д. 3. Ахметова, 3. Г. Нигматов, Т. А. Челнокова, Г. В. Юсупова и др.; под ред. Д. З. Ахметовой. Казань : Изд-во «Познание», 2013. $204 \mathrm{c}$.

6. Слепович Е. С., Харин С. С. Формирование у дошкольников с задержкой психического развития представлений о себе и других людях : Методические рекомендации. Минск : НИИ педагогики МНО БССР, 1989. 210 с.

7. Смирнова А. А. Психолого-педагогическая коррекция самооценки у подростков с ЗПР в условиях инклюзивного образования. Концеnт. 2018. № 4. Режим доступа: URL: https://cyberleninka. $\mathrm{ru} /$ article/n/psihologo-pedagogicheskaya-korrektsiya-samootsenki-u-podrostkov-s-zpr-v-usloviyahinklyuzivnogo-obrazovaniya (дата обращения: 18.06.2021).

8. Щербакова А. М. Роль среды в самореализации человека с интеллектуальной недостаточностью. Инклюзивное образование: методология, практика, технологии: Материаль международной научно-практической конференции (20-22 июня 2011, Москва). Редкол.: С. В. Алехина и др. Москва : МГППУ, 2011. С. 44-46.

\section{REFERENCES}

1. Dunaevskaia E. B. (2018). Osobennosty samootnoshenyia podrostkov, obuchaiushchykhsia v systeme ynkliuzyvnoho obrazovanyia. [Features of self-attitude of adolescents studying in the inclusive education system]. Problemy sovremennoho pedahohycheskoho obrazovanyia. (60-3). [in Russian]

2. Kuzava I. B. (2012). Rol inkliuzyvnoho seredovyshcha u formuvanni osobystosti doshkilnykiv, yaki potrebuiut korektsii psykhofizychnoho rozvytku. [The role of the inclusive environment in the formation of the personality of preschoolers who need correction of psychophysical development]. Pedahohichna osvita: teoriia i praktyka. (11), 315-318. [in Ukrainian]

3. Kuzmyna T. Y. (2009). Dynamyka formyrovanyia Ya-kontseptsyy u lyts s lehkoi stepeniu umstvennoi otstalosty [The dynamics of the formation of the self-concept in persons with a mild degree of mental retardation] (dyssertatsyia kandydata psykholohycheskykh nauk). Moskva. Rossyia. [in Russian]

4. Morozova N. L. (2008). Osobennosty formyrovanyia samovospryiatyia mladshykh shkolnykov $s$ yntellektualnum nedorazvytyem (dyssertatsyia kandydata psykholohycheskykh nauk). [Features of the formation of self-perception of primary schoolchildren with intellectual underdevelopment]. Nyzhehor. hos. ped. un-t. Nyzhnyi Novhorod. Rossyia. [in Russian]

5. Akhmetova D. Z., Nyhmatov Z. H., Chelnokova T. A. \& Yusupova H. V. (2013). Pedahohyka y psykholohyia ynkliuzyvnoho obrazovanyia: uchebnoe posobye. [Pedagogy and Psychology of Inclusive Education: A Study Guide]. D.Z. Akhmetova (red.). Kazan: «Poznanye». Tatarstan. [in Russian]

6. Slepovych E. S. \& Kharyn S. S. (1989). Formyrovanye u doshkolnykov s zaderzhkoi psykhycheskoho razvytyia predstavlenyi o sebe y druhykh liudiakh: Metodycheskye rekomendatsyy. [Formation in 
preschoolers with mental retardation of ideas about themselves and other people: Methodological recommendations]. Mynsk: NYY pedahohyky MHO BSSR. [in Russian]

7. Smyrnova A. A. (2018). Psykholoho-pedahohycheskaia korrektsyia samootsenky u podrostkov s ZPR v uslovyiakh ynkliuzyvnoho obrazovanyia. [Psychological and pedagogical correction of self-esteem in adolescents with mental retardation in the context of inclusive education]. Kontsept. (4). [in Russian]

8. Shcherbakova A. M. Rol sredy v samorealyzatsyy cheloveka s yntellektualnoi nedostatochnostiu. [The role of the environment in the self-realization of a person with intellectual disabilities]. Ynkliuzyvnoe obrazovanye: metodolohyia, praktyka, tekhnolohyy: Materyaly mezhdunarodnoi nauchno-praktycheskoi konferentsyy (s. 44-46). 20-22 yiunia, 2011, Moskva, Rossyia: MHPPU. [in Russian] 